\title{
Effect of splenectomy and ligature of the left gastric vein on portal hypertensive colopathy in carriers of surgical hepatosplenic schistosomiasis mansoni ${ }^{1}$
}

\author{
Efeito da esplenectomia e ligadura da veia gástrica esquerda na colopatia da \\ hipertensão porta na esquistossomose mansônica cirúrgica
}

\section{Claudia Rosalí Esmeraldo Justo² , Carlos Teixeira Brandt ${ }^{3}$, Maurilio Toscano Lucena², Martha Jales ${ }^{4}$}

1. Article from Department of Pediatric Surgery - University Hospital - Federal University of Pernambuco, Recife - Brazil.

2. Post-graduate student of Surgery, Faculty of Medicine - Federal University of Pernambuco.

3. Professor of the Department of Pediatric Surgery, Faculty of Medicine - Federal University of Pernambuco.

4. Medicine graduate student, Faculty of Medicine - Federal University of Pernambuco.

\begin{abstract}
Purpose: Esophageal variceal sclerotherapy and band ligation seem not to affect the endoscopic findings of Portal Hypertensive Colopathy (PHC) of cirrhotic patients. The aim was to assess the effect of splenectomy and ligature of the left gastric vein on the PHC in carriers of hepatosplenic schistosomiasis mansoni who underwent this surgery when they were between 9 and 18 year-old. Methods: Fourteen patients, mean age of 19.1 \pm 3.1 years, were included in the postoperative group (GI). The follow-up was from 1 to 9 years. The preoperative group (GII) consisted of nine patients, mean age of $14.0 \pm 3.1$ years. Full-length colonoscopy was carried out in all patients. Search was made for PHC lesions. Results: Telangiectasy (GI 100\% vs GII 100\%), increased vascularisation (GI 57.1\% vs GII 100\%), focal and diffuse hyperemia (GI 14.3\% vs GII 66.7\%), angiodysplasia (GI 7.1\% vs GII 33.3\%), and rectal varix (GI 0\% vs GII 55.6\%) were the most frequent findings. It was observed that the patients of this series tended to exhibit fewer hemodynamic manifestations of the PHC after treatment (postoperative versus preoperative $-\chi^{2}=8.155-p=0.004$ ). Conclusion: Splenectomy and ligature of the left gastric vein tend to reduce the abnormal vascular findings of PHC in carriers of hepatosplenic schistosomiasis mansoni.
\end{abstract}

Key words: Portal hypertension. Schistosomiasis mansoni. Splenectomy. Colopathy.

\section{RESUMO}

Objetivo: Avaliar o efeito da esplenectomia, ligadura da veia gástrica esquerda e auto-implante de tecido esplênico no omento maior, na CHP de jovens portadores de esquistossomose hepatoesplênica, que tinham se submetido a esse procedimento entre 9 e 18 anos. Métodos: Quatorze pacientes com média de idade de 19,1ะ3,1 anos, foram incluídos no grupo pós-operatório (GI), com seguimento de 1 a 9 anos. O grupo pósoperatório (GII) consistiu de nove pacientes, média de idade de 14,0 $\pm 3,1$ anos. Colonoscopia completa foi realizada em todos os pacientes. Pesquisaram-se lesões da CHP. Resultados: Telangiectasia (GI 100\% vs GII 100\%), aumento da vascularização (GI 57,1\% vs GII 100\%), hiperemia difusa ou focal (GI 14,3\% vs GII 66.7\%), angiodisplasia (GI 7,1\% vs GII 33,3\%), e varizes retais (GI 0\% vs GII 55,6\%) foram os achados mais freqüentes. Comparando o grupo pós-operatório versus pré-operatório $-\chi^{2}=8,155-\mathrm{p}=$ 0,004. Conclusão: Esplenectomia e ligadura da veia gástrica esquerda tendem a reduzir as alterações vasculares da CHP em portadores de esquistossomose hepatoesplênica.

Descritores: Hipertensão porta. Esquistossomose mansônica. Esplenectomia. Colopatia. 


\section{Introduction}

Portal hypertensive colopathy (PHC) was recognized as an entity in 1990. It was characterized by edema, generalized hyperemia in the colonic mucosa, increased vascularisation and hemorrhoids ${ }^{1-}$ ${ }^{3}$. The histological and histomorphometric description of this condition has been made in patients with liver cirrhosis and in those with schistosomiasis mansoni in its hepatosplenic form ${ }^{4-8}$. The experimental form of the entity in rats with cirrhosis also confirms the same changes found in human beings ${ }^{9}$.

Neither esophageal endoscopic sclerotherapy treatment (EST) nor endoscopic variceal band ligation (EVL), used for bleeding esophageal varices in patients with PHC, seem to alter the frequency and intensity of the histological findings in this entity ${ }^{10-11}$.

The purpose of this study was to evaluate the effects of splenectomy, ligature of the left gastric vein and autoimplantation of spleen tissue into an omental pouch of the greater omentum in adolescent carriers of hepatosplenic schistosomiasis mansoni (HSM) who underwent medical treatment and this surgical procedure when they were between 9 and 18 years old.

\section{Methods}

Fourteen carriers of HSM with bleeding esophageal varices and good liver function ( 9 females and 5 males; mean \pm SD age, $19.1 \pm 3.1$ years, range 13-23 years) were included in the postoperative study group (GI). All patients received medical treatment and underwent splenectomy, ligature of the left gastric vein and autoimplantation of spleen tissue into an omental pouch of the greater omentum, when they were between 9 and 18 years old. They were cared for at the Department of Pediatric Surgery - University Hospital -Federal University of Pernambuco, Recife, Brazil. Postoperative follow-up lasted from 1 to 9 years with a mean of 6 years.

The second group (GII), the preoperative control group, comprised 9 patients ( 6 females and 3 males; mean \pm SD age, $14.0 \pm 3.1$ years, range 9 - 18 years). These patients were also carries of the surgical hepatosplenic form of schistosomiasis mansoni. In 2003, they underwent the same medical and surgical treatments as the GI group.

All patients in both groups were given oxamniquine in a single dose of $20 \mathrm{mg} / \mathrm{Kg}$ of body weight for 30 days prior to surgery. The GI patients who proved positive for $S$. mansoni ova in the postoperative mucosal biopsy were given a second dose of oxamniquine.

All patients who had other conditions that might alter the evaluation of the colonic mucosa, such as viral hepatitis, renal disease, heart disease, nonsteroid anti-inflammatory drug use and pregnancy, were excluded from the study.

Full-length colonoscopy was performed in all cases using a colonoscope CF - VL, Olympus ${ }^{@}$ Tokyo, Japan, by a single investigator after colonic preparation. A careful search was made for lesions of PHC.

Anorectal varices were defined as bluish or gray distended, tortuous, or sacular veins seen well above the margin, extending into the rectum. Increased vascularization was defined by loss of the normal pattern, prominent vessels, irregular or normal vessels, with few areas without vessels. Telangiectasia was defined as tortuosity and engorgement of small vessels in the mucosal area of the colon. Angiodysplasia had a diameter of approximately $1 \mathrm{~cm}$ with a feeding vessel and a fur-ball appearance. Diffuse colonic dark erythematous changes were considered to be a hyperemia. Portal colopathy was defined as colitislike abnormalities and/or vascular lesions.

Two mucosal biopsies were routinely taken from the descending colon, sigmoid, and rectum. Additionally, a biopsy was taken from certain lesions of the colon that were considered to be related to the $S$. mansoni ova reaction. In every single biopsy a fresh search for $S$. mansoni ova was made under the microscope (quantitative oogram).

The investigation protocol was approved by the university's Ethics Committee. Written consent was obtained from parents before each session of endoscopy.

The chi-squared test was used for assessing possible differences among qualitative frequencies. $\mathrm{P}<0.05$ was adopted for rejecting the null hypothesis.

\section{Results}

Hyperemia of the colonic mucosa (Figure1), tortuosity and engorgement of small vessels (telangiectasy) in the colonic mucosa (Figure 2) - in some cases the angiodysplastic form (Figure 3) - were 
frequently found in both groups.

Rectal varices were seen in five patients of the preoperative group (Figure 4).

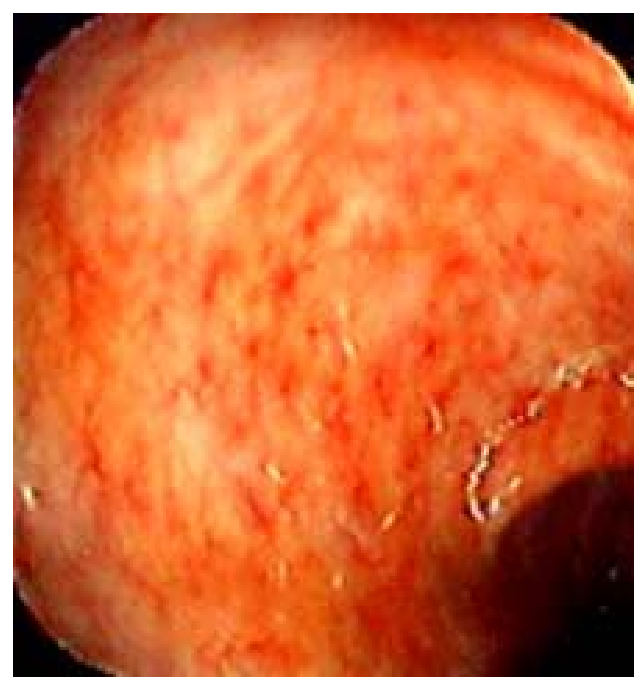

FIGURE 1 - Colonoscopic view of hyperemia of the colonic mucosa(GI).

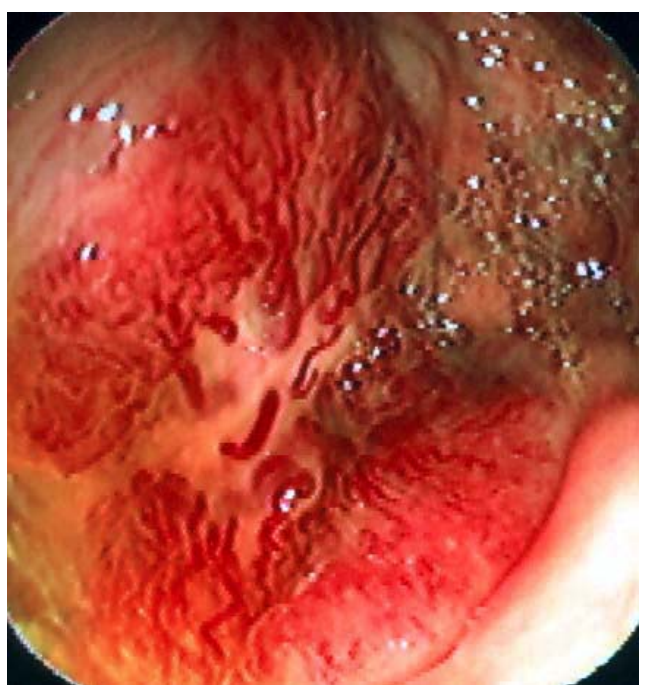

FIGURE 3 - Colonoscopic view of angiodysplastic-like lesions in the caecum (GII).

TABLE 1 - Frequencies of vascular abnormalities: colonoscopic findings in Group I

\begin{tabular}{lll}
\hline Colonic vascular abnormality & $\mathrm{n}$ & $\%$ \\
\hline Telangiectasy & 14 & 100 \\
Increased vascularisation & 8 & 57.1 \\
Hyperemia & 2 & 14,3 \\
Angiodysplasia & 1 & 7.1 \\
Rectal varix & 0 & 0 \\
\hline
\end{tabular}

TABLE 2 - Frequencies of vascular abnormalities: colonoscopic findings in Group II

\begin{tabular}{lll}
\hline Colonic vascular abnormality & $\mathrm{n}$ & $\%$ \\
\hline Telangiectasy & 9 & 100 \\
Increased vascularisation & 9 & 100 \\
Hyperemia & 6 & 66,7 \\
Angiodysplasia & 3 & 33,3 \\
Rectal varix & 5 & 55,6 \\
\hline
\end{tabular}

Chi squared for trend (pre-operative GII versus postoperative GI $-\chi 2=8.155-\mathrm{p}=0.004)$. 
In the five patients in GII group (preoperative group) who presented with rectal varices, the hemodynamic changes were similar to those who did not present with this condition.

Some findings specifically related to the S. mansoni colonic immune and inflammatory responses were found in both groups. Superficial and small ulcers were found in two patients in Group I and one in Group II. A large ulcer was found in one patient of each group. Three polyps (21.4\%) were found in Group I and two (14.3\%) in Group II. One patient from Group had an endoscopic finding similar to ulcerative colitis, with diffuse hyperemia and multiple ulcers measuring 2 to $3 \mathrm{~mm}$ in the entire colon and rectum.

In all biopsies taken from the GII patients, the search for S. mansoni ova was positive, while, in GI, five out of 14 patients (35.7\%) proved positive. One GI patient was found to have a remarkably large number of viable ova. A hard polyp covered by fibrin was observed in this patient, which was removed using a diathermic loop.

\section{Discussion}

The main objective of schistosomiasis control is morbidity control. It is also important to know the evolution of the disease in several organs after treatment, especially in patients with continuous exposure to the infection, as in the patients of this series. It is well known that liver abnormalities persist for at least six years after successful treatment of the S. mansoni ${ }^{12}$.

Endoscopic abnormalities such as inflammation and dilated tortuous vessels in the colonic mucosa are observed in $45 \%$ to $70 \%$ of carriers of schistosomiasis mansoni ${ }^{1,4}$. Granulomatous and pseudopolyp alterations can also be found. Some of these changes can be explained by the inflammatory and immune reactions to the ova of $\mathrm{S}$. mansoni in the colonic mucosa and submucosa. These changes were not significantly different in the two groups. It could be either that the medical treatment was not effective, leaving a residual parasite burden, or they may have been reinfected by the $\mathrm{S}$. mansoni, since they have been living in the same geographic area as before.

Portal hypertension, in patients with HSM, can also lead to hemodynamic disturbances, namely reverse blood flow in the left gastric vein and venous mesenteric system, throughout the gastrointestinal tract including the colon, producing further inflammatory and immune reaction changes to PHC. In this regard, the colonic findings are similar to those found in the stomach $^{13-15}$.

It has been observed that neither EST nor EVL significantly affect the hemodynamic changes in PHC in patients with liver cirrhosis ${ }^{10,11}$. On the other hand, the patients who develop rectal varices present with fewer major manifestations of PHC as compared with those who did not show this vascular disturbance. It seems that these varices decompress the rectal submucosal plexus, thereby decreasing the hemodynamic changes in this area ${ }^{10,11}$. In this study, however, the presence of rectal varices was not associated with fewer vascular abnormalities in the preoperative patients. With regard to the kind of treatment, both medical and surgical treatments in patients with HSM reduce the portal hypertension, and seem to influence the hemodynamics of the colon.

The lack of reaction in the PHC cirrhotic patients who had undergone EST and EVL is in contrast with the observation that these procedures affect the prevalence of hypertensive portal congestive gastropathy ${ }^{15,16}$.

The hypothesis that splenectomy and ligature of the left gastric vein may interfere with the manifestations of PHC in patients with HSM is based on the finding that this surgical procedure is associated, at long-term follow-up, with the reduction in size of the esophageal varices and the intensity of the gastropathy ${ }^{15,16}$. While the ligature of the left gastric vein may increase the reverse blood flow in the mesenteric system, in this respect being similar to EST and EVL, splenectomy, on the other hand, results in a major fall in portal pressure and may consequently compensate for the hemodynamic impact of the ligature of the left gastric vein in the colonic mucosa and submucosa.

Esophagogastric devascularization and splenectomy promote a significant reduction of the elevated portal pressure and flow in schistosomal portal hypertension ${ }^{17}$, which gives support to the concept that this surgical procedure may reduce varicose veins in the colon area, as it seems to have occurred in this investigation.

The hypothetical expected result of this investigation was that the GI patients, with a mean postoperative follow-up of 6 years, would present significantly fewer manifestations of PHC as compared 
with the GII patients. Contrary to this expectation, it needs to be stressed that approximately one in every three patients of the GII group, treated 30 days before surgery with a very effective drug (oxamniquine) to cure S. mansoni, presented a positive rectal mucosal finding for ova of this parasite. These patients may have been reinfected either because they were living in the same insanitary environment as before or because they have a residual parasitic burden infection. In any case, the continuation of egg deposition in the colonic submucosa may have maintained the immune response to these eggs, thereby aggravating the colopathy. In addition, the continued presence of the parasites in the portal system in one third of these patients may have mantained the flow of ova to the liver, triggering the immune reaction which leads to portal hepatic fibrosis (Symmers' fibrosis). As a result there could be a further increase in portal pressure, facilitating the reverse blood flow in the venous esophageal and mesenteric systems. This mechanism could produce a recurrence of upper digestive bleeding, as well as the persistence of PHC.

The patients of this series are young, present with a very good hepatic functional reserve and have no history of rectal bleeding. Thus, unlike cirrhotic patients, they are expected to present fewer manifestations of $\mathrm{PHC}^{4,8}$. Furthermore, it needs to be stressed that these young people represent a good model for assessing the vascular changes in the colon, after surgical treatment per se, because they do not yet present the degenerative factors related to the ageing process and exhibit good liver function.

From the results it can be concluded that the medical treatment of S. mansoni in young carriers of the surgical hepatosplenic form of this disease, followed by splenectomy, ligature of the left gastric vein and autoimplantation of spleen tissue into the greater omentum, tends to be associated, after long term follow-up, with a reduction in the vascular colonic findings of PHC, particularly regarding rectal varices, in these young patients.

\section{Conclusion}

Splenectomy and ligature of the left gastric vein tend to reduce the abnormal vascular findings of PHC in carriers of hepatosplenic schistosomiasis mansoni.

\section{References}

1. Mohamed AR, al Karawi M, Yasawy ML. Schistosomal colonic disease. Gut 1990; 31: 439-42.

2. Naveau S, Bedossa P, Poynard T, Mory B, Chaput JC. Portal hypertensive colopathy: a new entity. Dig Dis Sci. 1991;36:1774-81.

3. Kozarek RA, Botoman VA, Bredfeldt JE, Roach JM, Patterson DJ, Ball TJ. Portal colopathy: prospective study in patients with portal hypertension. Gastroenterology. 1991;101:1192-7.

4. Geboes K, El-Deeb G, El-Haddad S, Amer G, El-Zayadi. Vascular alterations of the colonic mucosa in schistosomiasis and portal colopathy. Hepatogastroenterology. 1995;42:343-7.

5. Lamps LW, Hunt CM, Green A, Gray GF, Washington K. Alterations in colonic mucosal vessels in patients with cirrhosis and noncirrhotic portal hypertension. Hum Pathol. 1998;29:527-35.

6. Dhiman RK, Saraswat VA, Choudhuri G, Sharma BC, Pandey R, Naik SR. Endosonographic, endoscopic, and histologic evaluation of alterations in the rectal venous system in patients with portal hypertension. Gastrointest Endosc. 1999;49:218-27.

7. Bini EJ, Lascarides CE, Micale PL, Weinshel EH. Mucosal abnormalities of the colon in patients with portal hypertension: an endoscopic study. Gastrointest Endosc. 2000;52:511-6.

8. Miranda MA. Colopatia hipertensiva portal na esquistossomose mansônica [Tese - Mestrado]. Universidade Federal de Pernambuco; 2002.

9. Onoda M. Experimental portal hypertensive colopathy in rats with liver cirrhosis. Nippon Shokakibyo Gakkai Zasshi. 2002;99:584-92.

10. Misra SP, Misra V, Dwivedi M. Effect of esophageal varicela sclerotherapy on hemorrhoids, anorectal varices and portal colopathy. Endoscopy. 1999;31:741-4.

11. Misra SP, Misra V, Dwivedi M. Effect of esophageal varicela band ligation on hemorrhoids, anorectal varices, and portal hypertensive colopathy. Endoscopy. 2002;34:195-8.

12. Richter J. Evolution of schistosomiasis-induced pathology after therapy and interruption of exposure to schistosomes: a review of ultrasonographic studies. Acta Tropica. 2000;77:111-31.

13. Misra SP, Dwivedi M, Misra V. Endoscopic and histological appearance of the gastric mucosa in patients with portal hypertension. Gastrointest Endosc. 1990;36:575-9.

14. Viggiano TR, Gostout CJ. Portal hypertensive intestinal vasculopathy: a review of the clinical, endoscopic and histopathological features. Am J Gastroenterol. 1992;87:944-54.

15. Iwao T, Toyanaga A, Sumino M. Portal hypertensive gastropathy in patients with cirrhosis. Gastroenterology. 1992;102:2060-5.

16. Brandt CT, Figueiredo JL, Almeida S, Guendler AV, Jucá N, Mandes S. Esquistossomose hepatoesplênica em 
jovens submetidos a esplenectomia e ligadura da veia gástrica esquerda: estudo prospectivo das varizes esofagianas. An Fac Med Univ Fed Pernambuco. 2002;47:14-7.
17. Cleva R, Saad WA, Herman P, Pugliese V, Zilberstein B, Laudanna AA, Rodrigues JJG. Portal hyperflow in patients with hepatosplenic mansonic schistosomiasis. Rev Hosp Clin Fac Med Univ São Paulo. 2004;59:10-4.
Correspondence:

Carlos Teixeira Brandt

Av. Boa Viagem, 5090/1201

51011-000 Recife-PE

Fax:(81)3342-0830

carlosbrandt@bol.com.br
Conflict of interest: none Financial source: none

Received: September 21, 2004

Review: November 05, 2004

Accepted: December 18, 2004

\section{How to this article:}

Justo CRE, Brandt CT, Lucena MT, Jales M. Effect of splenectomy and ligature of the left gastric vein on portal hypertensive colopathy in carriers of surgical hepatosplenic schistosomiasis mansoni. Acta Cir Bras. [serial online] 2005 Jan-Feb;20(1). Available from URL: $\underline{\text { http://www.scielo.br/acb }}$

Color figures available from www.scielo.br/acb 